\title{
LA PERSECUCIÓN DEL LULISMO EN LA CATEDRAL DE MALLORCA DURANTE EL EPISCOPADO DE JUAN DÍAZ DE LA GUERRA (1772-1777)
}

POR

FRANCISCO JOSÉ GARCÍA PÉREZ

Universidad de Granada

\section{RESUMEN}

El presente artículo analiza la represión ejercida por el obispo de Mallorca, don Juan Díaz de la Guerra, contra el culto luliano en la Catedral de Mallorca. Enfrentándose a los miembros del Cabildo, el obispo inició una persecución iconoclasta dentro del edificio catedralicio. Además, prohibió que ningún neófito pudiese ser bautizado con el nombre de Ramón. Esto degeneró en un profundo cisma en la élite eclesiástica mallorquina y afectó, inevitablemente, a todas las iglesias y conventos de Mallorca.

PALABRAS CLAVE

Obispo; Iulismo; cabildo; catedral; Mallorca.

THE PERSECUTION OF LULLISM IN THE CATHEDRAL OF MALLORCA FOR THE EPISCOPATE OF JUAN DÍAZ DE LA GUERRA (1772-1777)

\section{ABSTRACT}

This article examines the repression exercised by the Bishop of Mallorca, don Juan Díaz de la Guerra, against Llull worship at the Cathedral of Mallorca. Facing members of the chapter, the Bishop initiated an iconoclastic persecution inside the Cathedral building. In addition, he forbade any neophyte could be baptized with the name of Ramon. This degenerated into a deep schism in the Mallorcan 
ecclesiastical elite and affected, inevitably, all the churches and convents of Mallorca.

KEY WORDS

Bishop; Lullism; chapter; Cathedral; Mallorca.

Recibido/Received 09-12-2013

Aceptado/Accepted 17-02-2014

De entre todas las medidas diseñadas por el obispo de Mallorca Juan Díaz de la Guerra ${ }^{1}$ (1772-1777), la persecución del culto a Ramón Llull se ha convertido, sin ánimo de dudas, en la más famosa. La violencia de sus reformas religiosas sobre la Diócesis, las disputas entre la élite y la intransigencia del prelado hacia cualquier pacto posible, hicieron de su pontificado uno de los más odiados. Armado de una férrea convicción a la hora de constreñir la devoción, desencadenó una represión iconográfica y litúrgica de gran magnitud. Y fue tal su impacto, que se vivieron fuertes enfrentamientos en la cúspide civil y religiosa de la sociedad mallorquina. Entre éstos, como veremos a continuación, el Cabildo de la Catedral se declaró en abierta rebeldía al proyecto episcopal, utilizando el lulismo como su bandera de batalla en tal pugna.

Este artículo pretende el análisis de una parte de lo que supuso la represión antiluliana desencadenada por Díaz de la Guerra. Y más concretamente, su impacto en la Catedral mallorquina. Para tal fin, una parte queda dedicada al estudio de las medidas que implantó el obispo en la Seo -principalmente la persecución de la iconografía luliana y la censura episcopal sobre los bautismos-, y que, en muchos sentidos, sirvió de precedente para su aplicación en otras iglesias de la isla. Asimismo, se mostrarán aquí las estrategias que puso en práctica el

1 Juan Díaz de la Guerra nació en Jerez de la Frontera en 1727. Formado en su juventud en el tomismo por los padres dominicos, se trasladó a la ciudad de Granada donde llegó a ejercer la docencia en dicha Universidad. Hombre de un gran dinamismo, opositó hasta convertirse en canónigo de la Catedral de Toledo. Durante sus años en la sede primada, trabó grandes amistades, entre las cuales se hallaba la del futuro arzobispo de Toledo, Francisco de Lorenzana. A continuación, se trasladó a la corte de Madrid, donde se rodeó de gentes de influencia que lo ayudaron en su imparable ascenso. Hasta el punto de que se convirtió en auditor de la Rota romana. Fue durante su estancia en Roma cuando en 1772, recibió la noticia de su traslado a la mitra de Mallorca. Rosselló Lliteras, J. 1988. "Don Juan Díaz de la Guerra (s. XVIII)". Estudios Lulianos 28: 51-70. 
Cabildo catedralicio para frenar la política antilulista, y sus consecuentes enfrentamientos con el obispo Díaz de la Guerra.

\section{EL CULTO LULIANO Y EL PATRONAZGO DE LA CATEDRAL DE MALLORCA}

El culto a Ramón Llull venía desarrollándose en la isla de Mallorca desde la misma muerte del Doctor Iluminado. Hacia finales del siglo XIV había comenzado a configurarse todo un ceremonial e iconografía religiosos en su nombre; los seguidores de Llull lo consideraban un auténtico santo ${ }^{2}$ y las masas le profesaban una abnegada piedad religiosa. Su sepultura, primeramente dispuesta en la sacristía del convento de San Francisco, había quedado expuesta a la veneración de los fieles desde 1448. Para tal fin, el lulista Joan Llobet había diseñado un bellísimo féretro, que fue colocado en una de las capillas de la iglesia conventual. Además, se le dedicaban dos fiestas anuales, se celebraban misas en su honor y la iconografía luliana no había dejado de expandirse por diferentes templos de Mallorca. Esta situación desembocó, a lo largo de la Edad Moderna, en un fortalecimiento progresivo de la devoción, siempre al amparo de patrocinadores que velaron por su abundancia. Entre éstos se hallaban algunas órdenes religiosas de gran influencia, como los padres franciscanos o los jesuitas, así como miembros de la élite civil de la isla. Sin embargo, cabe resaltar el papel trascendental que jugaba el Cabildo de la Catedral.

Los miembros del Cabildo habían mostrado siempre una especial predilección hacia el culto luliano. Junto con los otros patronos del Mártir, los Jurats de la Ciutat i Regne de Mallorca ${ }^{3}-\mathrm{y}$, desde el siglo XVIII, sus sucesores directos, los regidores del Ayuntamiento de Palma- se entregaban a la organización de grandes ceremonias religiosas. Además, como uno de los grandes baluartes prolulianos, el Cabildo se había autoproclamado fiel protector de la Causa Luliana, con el deber y el honor de "conservar la buena memoria del dicho Beato Raymundo, y que

\footnotetext{
${ }^{2}$ Ferrer i Flórez, M. 2001. "Culte a Ramon Llull: discòrdies i controvèrsies". Studia Lulliana 41: 65.

${ }^{3}$ Máxima institución representativa del reino de Mallorca, los Jurats, provenientes de los principales estratos sociales de la isla, se ocupaban durante la Edad Moderna de todas aquellas competencias de gobierno y administración que no estuviesen adjudicadas al virrey. Desaparecieron tras el final de la Guerra de Sucesión y la entrada de las tropas borbónicas en la isla. Una vez implantados los Decretos de Nueva Planta, los jurados de Mallorca se convirtieron, juntamente con el Gran i General Consell, órgano consultativo del Reino, en una reliquia de los tiempos de los Habsburgo. Juan Vidal, J. 2010. El sistema de gobierno del reino de Mallorca: 345 Palma: El Tall; Planas Rosselló, A. 2005. Los Jurados de la Ciudad y Reino de Mallorca (1249-1718): Palma: Lleonard Muntaner.
} 
no se haga injuria a ella". ¿ ¿Pero cuáles eran los motivos que incitaban a esta corporación a defender tan apasionadamente el lulismo? Lo cierto es que siempre fueron complejos, y caminaron en consonancia con las grandes ambiciones e intereses de los miembros capitulares.

En primer lugar, uno de esos motivos estaba ligado a una cuestión harto importante: la intercesión religiosa de Ramón Llull para la llegada de las lluvias. Desde tiempos inmemoriales, se le rezaba para que mediase ante el Altísimo y así salvar a sus habitantes de las temidas sequías. ${ }^{5}$ Ante una isla que se veía sometida tan frecuentemente a las inclemencias meteorológicas, llegando a producirse terribles hambrunas, la población mallorquina veía en los santos y beatos un símbolo de esperanza: sus intermediarios ante Dios. A ellos, y en especial al beato Llull, se les oraba para que cada año llegasen lluvias abundantes que bañasen los campos y librasen al pueblo del hambre y la miseria. En este sentido, no debe extrañarnos observar que, más allá de una ferviente veneración vocacional, el Cabildo catedralicio, como parte de los grupos privilegiados, incentivara el culto luliano como un modo de calmar a las masas campesinas. Así se evitaba el peligro de amotinamientos populares y crisis sociales ante la falta de precipitaciones y la consecuente escasez de trigo. ${ }^{6}$

Su segunda motivación para la defensa del culto luliano se hallaba, probablemente, muy ligada a su posición en la cúspide eclesiástica de la

${ }^{4}$ Archivo Capitular de Mallorca -en adelante ACM-, AC, 1660, 053. 28 de diciembre de 1774, f. 292 r.

5 Algunos trabajos han sabido dar testimonio de las dificultades económicas $y$, en su repercusión, también sociales, que se vivieron en la isla entre los siglos XVI y XVIII. A crisis agrarias, que reportaban el hambre y la miseria de gran número de familias mallorquinas, se le sumaba un cuadro epidemiológico, en ocasiones, devastador. Juan Vidal, J. 1976. "Crisis agrarias y la sociedad en Mallorca durante la Edad Moderna". Mayurqa 16: 87-113; Contreras Mas, A. 2008. "Epidemiología rural mallorquina a fines del siglo XVIII". Trabajos de Geografía 37: 83-90.

${ }^{6}$ En el año de 1750 , en medio de una terrible sequía que provocó hambrunas y miseria en toda la isla, se celebraron rogativas a Ramón Llull, coincidiendo con la llegada de lluvias torrenciales que provocaron una inmensa alegría en todos los sectores sociales de Mallorca. Cuando se celebró un Te Deum para dar las gracias a la intercesión del Beato, el hecho de que algunos miembros de la élite religiosa, como los dominicos, no asistiesen, provocó una grave tensión social. Sobre todo en la Part Forana, la pagesia mallorquina se enfureció ante los ultrajes de los padres predicadores y las grandes instituciones de poder observaron los peligros de injuriar el culto a Ramón Llull. Véase Pérez Martínez, L. 1989. "Un capítulo sobre el lulismo mallorquín, el Te Deum de 1750". Bolletí de la Societat Arqueològica Lul-liana 45: 333-341; Ferrer i Flórez, M. 2003. "La convulsió de 1750 referent al culte de Ramon Llull”. Studia Lulliana 43: 103-126. 
isla. El poder de los guardianes de la Catedral era considerable. No sin razón, la gran mayoría de sus miembros formaba parte del estamento nobiliario mallorquín. Tanto es así que se había convertido en una voz autóctona, ${ }^{7}$ que disponía de una influencia social de primer orden, muy capaz de hacer frente a los sucesivos mitrados que llegaban a la diócesis. En consecuencia, había adquirido, al igual que en la mayoría de las diócesis españolas, una "mayor independencia, [...] de forma que el tema de su excepción de la jurisdicción episcopal será motivo de continuos conflictos entre ambos poderes a lo largo de los siglos". ${ }^{8}$ Haciendo gala de una influencia social de primer orden, y muy receloso de sus privilegios, el Cabildo utilizó la devoción al Mártir como una más de sus armas, para reafirmar su ascendencia y poder ante el resto de miembros del estamento eclesiástico. Más aún cuando, dentro del mismo, se habían experimentado no pocos incidentes relacionados directamente con la cuestión luliana.

Pese a la amplia mayoría proluliana, entre la que se enmarcaba, como no podía ser de otro modo, el Cabildo catedralicio y algunas órdenes religiosas como los franciscanos o los jesuitas, existían sectores que clamaban la condenación del lulismo. Grupos antilulianos cada vez más reaccionarios que consideraban que la devoción no merecía la aprobación papal. ${ }^{9}$ Entre éstos, los dominicos encabezaron un papel protagonista, consiguiendo "atraerse a algunos importantes eclesiásticos de la Diócesis mallorquina". ${ }^{10}$ Esta situación había degenerado en una confrontación intermitente que empañó las relaciones en la cúspide eclesiástica mallorquina. La premura del Cabildo por defender la devoción ante tales ataques, lo llevó a iniciar auténticas campañas prolulianas. No son pocos los ejemplos que demuestran esta visceral

7 Amengual i Batle, J. 2002. Història de l'Església de Mallorca. Del Barroc a la II-lustració (1563-1800): 103 Palma: Lleonard Muntaner.

${ }^{8}$ Barrio Gozalo, M. 2010. El clero en la España Moderna: 199 Córdoba: CSIC.

${ }^{9}$ En paralelo al auge de la veneración luliana, se formaron grupúsculos claramente antilulianos. Estos enemigos del Beato condenaron el pensamiento de Ramón Llull como herético y, con el paso de los siglos, fueron fortaleciendo su influencia a nivel social y religioso. En la Mallorca Moderna, fueron formándose dos facciones entre el pueblo, aquellos que adoraban ciegamente a Llull, llamados teuladers o gorrions, y aquellos que no dudaron en negar su adhesión al culto, los marrells. Estos segundos, capitaneados por los padres dominicos, se vieron cada vez más fortalecidos durante el siglo XVIII. Por ello, cuando Díaz de la Guerra llegó a Mallorca y emprendió su represión antiluliana, podemos localizar un frente de presión vigoroso y dispuesto a todo para expulsar de la isla todo atisbo de lulismo. Ferrer i Flórez, M. 2001: 65-89.

${ }^{10}$ Ramis Barceló, R. 2012. "La imposición del nombre de Ramon Llull en el bautismo: dos casos jurídicamente controvertidos en Mallorca durante el año 1763". Hispania Sacra 64: 263. 
actuación por parte de los canónigos durante los siglos XVII y XVIII, pugnando por la validez del culto público $y$, al mismo tiempo, consolidando su preeminencia en lo más granado del poder religioso.

Cuando en 1699 apareció destruida una talla de Llull en la Universidad Luliana de Mallorca, el Cabildo se unió al obispo Pedro de Alagón (1684-1701), en su campaña para condenar el atropello iconográfico y validar la devoción. ${ }^{11}$ Asimismo, los canónigos aplaudieron la firme determinación del obispo Llorenç Despuig (1750-1763) al lanzar un decreto de excomunión sobre los culpables de un ultraje cometido hacia las imágenes del Mártir en el año de $1755 .{ }^{12}$ Pero, yendo todavía más lejos, planificaron un auténtico boicot sobre la Orden de Predicadores, después de que éstos ofendiesen al Beato y a sus devotos, negándose a asistir a un Te Deum organizado para dar gracias por la intercesión religiosa que había traído las lluvias a la isla.

A la hora de legitimar su patrocinio al culto a Ramón Llull, el Cabildo contaba con una serie de estrategias, todas ellas de una larguísima tradición arraigada en los inicios de la Edad Moderna. Éstas tenían una variada gama, yendo desde su participación activa en el ceremonial luliano, a la confección de todo un programa iconográfico y litúrgico, que se desarrollaba tras las grandes puertas de la Catedral. Cada una de las maniobras que utilizó el Cabildo para patrocinar la devoción, conllevaron una consecuencia doble. Por un lado, posibilitaron el fortalecimiento progresivo del culto luliano. A fin de cuentas, el mecenazgo catedralicio sirvió de ejemplo e inspiración para el resto de iglesias de la isla. Pero también, insertó a los capitulares en el complejo juego del lulismo, obligándolos a implicarse visceralmente en un culto que, con cada año que pasaba, iba asumiendo una controversia aún mayor, siempre ante la amenaza acechante del antilulismo. Veamos, pues, algunas de esas maniobras prolulianas.

Una de las más importantes, y que había sido cita obligada entre la élite eclesiástica a lo largo de los siglos modernos, fue su participación en las festividades anuales dedicadas a Llull en la ciudad de Palma. Desde hacía siglos, los canónigos habían tenido un lugar de honor en las celebraciones. Asimismo, era ordinaria su presencia en tedeums, rogativas y fiestas, así como en las misas organizadas a la gloria del Beato. Año tras año, el Ayuntamiento de Palma les enviaba invitaciones formales para su asistencia a estas ceremonias:

${ }^{11}$ Cassanyes Roig, A. y Ramis Barceló, R. 2012. "El atentado antiluliano de 1699 en el marco ideológico de la Universidad de Mallorca". Memòries de la Reial Acadèmia Mallorquina d'Estudis Genealògics, Heràldics i Històrics 22: 141-166.

${ }^{12}$ Arxiu del Regne de Mallorca -en adelante ARM-, Lul-lisme, 74, s/f. 
Que la Ciudad por la buena armonía con que siempre había corrido con el muy llustre Cabildo, lo participaba a S.S. pidiéndole que, como y otras veces lo había hecho, se dignara a asistir a la función a fin de ayudarla [a la Ciudad] a dar gracias a Dios Nuestro Señor por el beneficio que acababa de hacernos por medio de Nuestro Patricio [Ramón Llull]. ${ }^{13}$

En cuanto a la sede catedralicia, ésta capitaneaba, en muchos sentidos, el gran boato luliano que se daba en Mallorca desde siglos atrás. En primer lugar, la Catedral incluía en su programa iconográfico algunas referencias a Ramón Llull, ${ }^{14}$ algo que se hacía extensible a un gran número de iglesias de Palma y la Part Forana. Por poner algunos ejemplos, en la sacristía capitular se hallaban estampas con elogios de Sant, así como algunas tallas, todas ellas imágenes de Ramón Llull, que se habían contemplado desde días inmemoriales -según contaban en sus escritos algunos de los grandes defensores del lulismo- ${ }^{15}$ Además, en la capilla de San Sebastián podía localizarse una escultura de Llull "como doctor iluminado, [...] vestido con hábito de franciscano y capa, con un libro y pluma y el haz de rayos alrededor de la cabeza". ${ }^{16}$ Pero yendo todavía más allá, muchos miembros del personal relacionado directa o indirectamente con la mensa capitular, solían guardar estampas lulianas en sus habitaciones.

En segundo lugar, el hecho de que Ramón Llull fuese considerado beato por aclamación popular, lo dotaba de un lugar de honor en el santoral mallorquín. La veneración profesada por cientos de familias mallorquinas tenía su repercusión directa en los bautismos. Como es bien sabido, en la tradición católica, los neófitos recibían los nombres de los santos y beatos de la Cristiandad. En el caso de Llull, desde finales de la Edad Media, los niños y niñas bautizados comenzaron a tener entre sus nombres el de Ramón y Ramona, en su honor. Año tras año, los domeros de la Catedral -asistentes de los canónigos en el santo sacramento del bautismo en el sí de la sede catedralicia- solían incluir, a petición de los padres de las criaturas, el nombre de tan Invicto Mártir. Era una tradición que pocos cuestionaban y que se continuaba de generación en generación, siendo no sólo tolerada, sino promovida por

${ }^{13}$ ACM, AC, 1660, 052. 25 de noviembre de 1774, f. 277 v.

14 Sacarès Taberner, M. 2006. "Lulliana imagines: la iconografia luliana de Ramon Llull i els principals episodis de la seva vida". Memòries de la Reial Acadèmia Mallorquina d'Estudis Genealògics, Heràldics i Històrics 16: 139-156.

${ }^{15}$ Custurer, J. 1700. Disertaciones históricas del culto al Beato Raymundo Lulio: 573 Palma: Imp. Miguel Capó.

16 Cantarellas Camps, C. 2005. "Iconografía luliana: prototipos y desarrollo histórico". Bolletí de la Societat Arqueològica Lul-liana 61: 221. 
ciertos obispos de Mallorca, como Llorenç Despuig ${ }^{17}$ o los mismos canónigos catedralicios.

En esencia, queda constatada la imagen de un Cabildo eclesiástico que, desde hacía siglos, participaba activamente de una devoción que llenaba de júbilo a gran parte de la población mallorquina. Su mecenazgo y patrocinio eran esenciales para el sostenimiento del lulismo moderno. Con su participación validaba, en gran medida, la trayectoria vital del culto y lo acreditaba frente a los ataques de grupos antilulianos cada vez más virulentos. $Y$ asimismo, su tesón en la defensa del culto, que había llevado a los capitulares a iniciar auténticas campañas sobre aquéllos que planifican la condenación del lulismo en Mallorca, dejó clara su postura frente a aquel complejo y cada vez más enrarecido asunto. Sin embargo, la prueba de los miembros capitulares en cuanto a su implicación en la defensa proluliana todavía estaba por llegar. En efecto, sólo el paso del tiempo testimonió el verdadero papel que jugaron los canónigos en su protección, especialmente cuando un nuevo obispo decidió que el lulismo ya no merecía tal consideración eclesiástica.

\section{LA POLÍTICA REPRESORA DE JUAN DÍAZ DE LA GUERRA EN EL CONTEXTO DEL REFORMISMO BORBÓNICO}

Cuando Juan Díaz de la Guerra arribó a la isla en 1772, lo hizo con grandes planes en su mente. Como obispo de su tiempo, y firme defensor de la política ilustrada de Carlos III, no dudó en guiarse siempre por los proyectos reformadores que se estaban diseñando en la Corte de Madrid. ${ }^{18}$ En lo que respecta al ámbito religioso, la campaña antilulista que capitaneó, y sus consecuentes enfrentamientos con el Cabildo, se enmarcan dentro de las dinámicas religiosas de la segunda mitad del siglo XVIII. Éstas se caracterizaron por un sometimiento progresivo de la Iglesia a las exigencias del Estado, que pasó a controlar todos los ámbitos de la vida religiosa del Setecientos. ${ }^{1}$

Desde los inicios de su reinado, Carlos III se había adjudicado el monopolio sobre la Iglesia católica bajo sus dominios, desplegando una imponente política religiosa. En líneas generales, planificó "intervenciones estatales en asuntos espirituales [...]. [Un] auténtico abuso de poder con el deseo de conseguir una sujeción lo más completa

${ }^{17}$ Ramis Barceló, R. 2012: 275.

18 Para una visión general de las políticas religiosas diseñadas por Carlos III a lo largo de su reinado, véase Herr, R. 1971. España y la revolución del siglo XVIII: Madrid: Aguilar; Sánchez Blanco, F. 2002. El absolutismo y las luces durante el reinado de Carlos III: Madrid: Marcial Pons.

${ }^{19}$ Woloch, I. 1982. Eighteenth-century Europe. Tradition and Progress, 1715-1789: 273 New York: Norton \& Company. 
posible de la Iglesia al Estado". ${ }^{20}$ Por tanto, las ambiciones del Borbón iban dirigidas a controlar todo el entramado eclesiástico. Y para tal fin, necesitaba de una nueva casta de obispos reformadores y fieles a sus proyectos que, sin pestañear, aplicasen sus designios sobre las respectivas diócesis. Díaz de la Guerra fue uno de estos prelados. Durante su pontificado, la violencia de sus reformas constató su decisión de implantar cambios, aún a costa del bienestar general en la isla.

Entre los planes reformadores del obispo, como venimos diciendo, se hallaba el constreñimiento del culto luliano. Un episodio que, lejos de considerarse un acontecimiento atípico en el contexto hispánico, estuvo íntimamente relacionado con las líneas de reforma y transformación de la vida religiosa que distintos obispos estaban abanderando en sus respectivas diócesis. Especialmente en lo que se refiere a devociones populares. ${ }^{21} \mathrm{~A}$ fin de cuentas, la religiosidad del siglo XVIII se caracterizó por un progresivo recelo de las élites hacia la espontaneidad y el carácter desatado que se había vivido en el Barroco. Las flagelaciones públicas, las devociones marianas o la autonomía ejercida por las cofradías, todas ellas formas de devoción cada vez más monopolizadas por las capas populares, quitaban el sueño al monarca. Por ello, lejos de potenciar estas veneraciones, Carlos III y sus fieles prelados sometieron toda forma de religiosidad popular que pudiese entrañar peligros para la estabilidad social. ${ }^{22}$

Entre estos cultos populares de una naturaleza tan variada, el lulismo también comenzó a ser visto con recelo. Pese a contar con el respaldo de los sectores privilegiados -además de con el importante fervor popular-, en absoluto podía pasar inadvertido. Hacía años que las

20 Cortés Peña, A. L. 1989. La política religiosa de Carlos III: 27 Granada: Universidad de Granada.

${ }^{21}$ En paralelo a la represión antiluliana de Juan Díaz de la Guerra, en otras zonas de la Monarquía, distintos obispos estaban persiguiendo devociones populares en sus respectivas diócesis. En Cataluña, el obispo Climent había perseguido el fanatismo y las supersticiones en su sede en Barcelona; por otro lado, el arzobispo de Valencia, Fabián y Fuero, prohibió la exposición de exvotos en las iglesias, larga tradición en la diócesis valenciana. Martí Gelabert, M. 2004. Carlos III y la política religiosa: 58 y ss. Madrid: Rialp.

22 El profesor López-Guadalupe ha estudiado la religiosidad dieciochesca, poniendo especial énfasis en la represión institucional ejercida sobre las devociones populares, principalmente sobre las cofradías y otros cultos locales y minoritarios. En sus estudios, muestra la confrontación entre una religiosidad popular que había gozado de una gran aceptación social en el Seiscientos, frente a una religiosidad de élite mucho más austera y firmemente sometida. López-Guadalupe, M. L. 2006. "Religiosidad institucional y religiosidad popular", en A. Cortés Peña. (Coord.), Historia del Cristianismo 3: 415-464. Granada: Universidad de Granada. 
rivalidades entre una mayoría proluliana, capitaneada entre otros grupos por el Cabildo, y una minoría antiluliana cada vez más agresiva, teñían las ceremonias de violentas disputas.

El pueblo mallorquín se había visto sacudido por las desavenencias doctrinales que habían pesado sobre el culto desde los siglos medievales. Tanto es así, que el fervor luliano que se experimentaba en las capas populares, a menudo terminaba en trifulcas y disturbios sociales cada vez más difíciles de controlar. Hasta el punto de que, a partir de la segunda mitad del siglo XVIII, se había desencadenado una dinámica de violencia social en torno al lulismo, entre aquéllos que pretendían boicotear la devoción y una gran mayoría que, valiéndose de todos los medios a su alcance, velaba por su supervivencia. Por poner algunos ejemplos, en los recorridos de las procesiones lulianas programadas anualmente, se habían dado episodios de insultos sobre el Beato que habían degenerado en peleas callejeras. Asimismo, los conventos dominicos habían sufrido la ira del pueblo llano mediante ataques directos, en los que se mezclaban insultos y pedradas. $^{23}$

Esta alarmante situación ya había sido tenida en cuenta por el monarca años antes de la llegada de Díaz de la Guerra a su nueva diócesis. Las políticas implantadas por Carlos III en Mallorca, a través de la figura del Capitán General Francisco de Bucareli y Ursúa (1761-1765), habían iniciado una campaña de medidas que perseguían limitar la influencia luliana, presagiando los días de persecución antilulista asumidos por el Obispo. El Comandante, "apoyado en los dominicos y sus seguidores, empezó a tejer una red poderosa que cristalizó en una mayoría antiluliana en lo político, jurisdiccional y religioso". ${ }^{24}$ El Cabildo catedralicio se había opuesto con perseverancia a muchas de las líneas de actuación planificadas por Bucareli, sobre todo en lo tocante al culto. Haciéndose valer de su lugar en la cúspide eclesiástica, se había unido a otros de los tradicionales baluartes prolulianos en la élite mallorquina como el Ayuntamiento de Palma- y había condenado distintos procederes del Comandante. Y, en muchos sentidos, había conseguido imponer su ascendiente social para frenar la escalada de desprestigio y recelo que se cernía sobre el lulismo mallorquín.

Sin embargo, fue con Díaz de la Guerra cuando la situación en torno al culto luliano llegó a niveles nunca antes sospechados. El nuevo obispo, lejos de comprender la naturaleza de la devoción, y viéndola como un peligro para implantar sus reformas, inició desde muy pronto una campaña destinada a eliminar las bases institucionales del culto y

${ }^{23}$ Pérez Martínez, L. 1989: 340.
${ }^{24}$ Ramis Barceló, R. 2012: 265. 
debilitar el apoyo popular que lo sostenía desde hacía siglos. ${ }^{25}$ Los ataques al Cabildo de la Catedral fueron parte importante en el proyecto de desestabilización institucional del lulismo. A fin de cuentas, el prelado conocía el papel que jugaban los capitulares y no dudó en iniciar duros enfrentamientos. Unas disputas en el seno del poder religioso que parecían esconder dos objetivos, firmemente perseguidos por el diocesano.

El primero de ellos tenía un carácter litúrgico y devocional. Díaz de la Guerra sabía que, para erradicar de forma firme el culto luliano, debía enfrentarse al otro gran poder religioso de Mallorca. Si imponía sus designios en la Seo -lo que implicaba nada menos que intervenir directamente sobre el programa ceremonial e iconográfico administrado por el Cabildo- sería más fácil implantar sus medidas en el resto de iglesias y conventos de la isla. Además, dejando fuera de juego a los canónigos, el mitrado eliminaba a otro de los grandes baluartes que potenciaban el culto público.

El segundo motivo tenía sus lazos en las históricas disputas de poder y jurisdicción que existían entre ambas instituciones eclesiales. Prelados anteriores se habían visto obligados a pactar sus políticas con un Cabildo muy receloso de sus privilegios y ascendiente social. Pero lejos de continuar la tradición, Díaz de la Guerra se identificaba como un obispo entregado al proyecto ilustrado de Carlos III. Sometiendo a los capitulares, estaba reproduciendo las políticas absolutistas que irradiaban desde la Corte, y, al mismo tiempo, demostraba a todos los miembros del estamento eclesiástico, que su poder en el ámbito religioso era incuestionable. Por ende, mediante una actitud despótica, el prelado perseguía imponer sus designios, seguramente convencido de que la erradicación del lulismo era un bien necesario que la élite mallorquina todavía no lograba asimilar.

\section{LOS INICIOS DE LA REPRESIÓN: LA PERSECUCIÓN DE LA ICONOGRAFÍA LULIANA}

Desde los primeros meses de pontificado, finalizando ya el año de 1772, Díaz de la Guerra mostró una clara aversión al culto a Ramón Llull. A sus constantes renuncias a asistir a actos en honor al Beato -como las fiestas anuales de la Conversió y el Martiri-, se unía su actitud esquiva, cuando no claramente defensora de atropellos antilulianos. Todo ello despertó los primeros recelos entre los miembros de la cúspide civil y religiosa de Mallorca. El Ayuntamiento de Palma y el Cabildo de la Catedral exigían que el mitrado actuase con firmeza en contra de

${ }^{25}$ Pérez Martínez, L. 1988. "Don Juan Díaz de la Guerra y el lulismo". Anales Seguntinos 5: 95-114. 
aquéllos que boicoteaban la devoción inmemorial de Llull. Pero Díaz de la Guerra no hizo nada.

Al contrario, menos de dos años después de arribar a la isla, desató sus políticas represoras, destinadas a erradicar todo vestigio de lulismo. Una campaña dirigida por él mismo y sostenida por distintos sectores enemigos del lulismo, que se convirtieron en una auténtica camarilla. ${ }^{26}$ Ésta persecución se caracterizó, en primer lugar, por unas medidas claramente radicales, nunca antes conocidas en la historia de la Iglesia mallorquina. Además, supuso una auténtica desestabilización del culto público, pues era la primera vez que un obispo negaba de forma abierta su asistencia a la devoción, llegando a condenarla abiertamente.

Una de las medidas que abrió el camino de la campaña antiluliana, fue la persecución de la iconografía dedicada a Ramón Llull. Una auténtica represión iconoclasta que afectaba a todos los templos y conventos de la isla, pero que tuvo una enorme trascendencia en el edificio de la Catedral.

Todo comenzó durante los últimos meses de 1774. Las relaciones en el seno del poder eclesiástico mallorquín eran tensas. De continuo, el obispo se negaba a pactar sus decisiones con el Cabildo. Al contrario, continuaba sus planes de reforma haciendo oídos sordos a las demandas que recibía de los otros grupos de poder. ${ }^{27}$ Pero todo se radicalizó más aún, cuando Díaz de la Guerra hizo publicar un nuevo edicto episcopal, que determinó el auténtico inicio de la empresa antiluliana: "el ilustrísimo Obispo y su Vicario General han acordado algunos decretos en que prohíben el uso de ciertas estampas del Beato Raymundo Lulio". ${ }^{28}$ Bajo pena de multa, las estampas donde aparecía el Doctor Iluminado debían ser inmediatamente eliminadas de los edificios religiosos, ya que contenían elogios y apelativos no aceptados por la Santa Sede, como el de Sant.

26 Distintos historiadores mallorquines han hecho referencias a la existencia de una camarilla episcopal, alrededor de la figura de Díaz de la Guerra. Sus integrantes no fueron pocos, pero entre ellos, los más importantes fueron Gabriel Carrió, vicario general; el canónigo y catedrático Antonio Bisquerra y, el más famoso de todos, Antonio Peña, el secretario personal del obispo. Furio i Sastre, A. 1852. Episcopologio de la Santa Iglesia de Mallorca: 510 Palma: Imp. Gelabert; Mateu Mairata, G. 1985. Obispos de Mallorca: 451 Palma: Cort; Rosselló Lliteras, J. 1988: 58 y ss.

27 Meses antes de iniciar la represión iconográfica luliana, Díaz de la Guerra había hecho desaires al culto, como su negativa a que se expusiese el santísimo sacramento en las ceremonias lulianas de San Francisco, o el cierre del colegio de la Sapiencia, otro de los bastiones del lulismo doctrinal.

${ }^{28}$ Archivo Municipal de Palma -en adelante AMP-, AH 2099/3. 27 de diciembre de 1774, f. 86 . 
Buscando imponer su autoridad, y a sabiendas de la probable oposición que iba a recibir de los canónigos, el primer lugar donde Díaz de la Guerra actuó fue en la sede catedralicia. Sin tardanza, envió sus designios a la sala capitular y, dejando muy claras las consecuencias de cualquier tipo de subversión, ordenó:

que bajo pena de 50 libras retirase [el sacristán] la Estampa del Beato Lulio que estaba dentro de la Sacristía Mayor, y que contenía Dictados y elogios de Sancto; [...] [El obispo] le había intimado un nuevo mandato en que bajo la pena de otras 50 libras le ordenaba retuviese dichas Estampas, prohibiendo las entregase a nadie sin su permiso, después de cuyas dos íntimas, [...] le había hecho otra en que bajo la pena de otras cincuenta le mandaba que antes de anochecer le hubiese entregado las dos estampas mencionadas. ${ }^{29}$

La noticia generó indignación y desconcierto. Una vez se reunieron en capítulo, los canónigos discutieron acaloradamente sobre las estrategias a seguir para frenar el decreto. Entre sus miembros, la mayoría aconsejaba la resistencia total, pero existían obstáculos importantes. Por un lado, la orden diocesana ya estaba circulando por muchas iglesias de la Diócesis, y no eran pocos los párrocos que comenzaban a retirar las imágenes lulianas de altares y capillas, dificultando la capacidad de actuación del Cabildo. Pero aún existía un segundo obstáculo. Entre los componentes del Cabildo, había fieles seguidores del obispo Díaz de la Guerra. Algunos habían observado satisfechos que, por fin, un prelado se decidía a eliminar un culto que consideraban incómodo y no validado por el Papado. Entre éstos, el canónigo Antonio Bisquerra, ${ }^{30}$ catedrático de Instituta en la Universidad Literaria de Mallorca, se había declarado firme defensor de las políticas del prelado. Y cuando le tocó dar su parecer sobre el decreto episcopal, su defensa fue absoluta:

En fuerza de su cargo, [el obispo] está constituido legítimo Juez para declarar cuales sean las Estampas semejantes. [...] Tiene autoridad para prohibir cualquiera pintura o imagen que no conforma con las circunstancias del Sujeto que representa Ibi. [...] Y no solamente tiene el Diocesano la Autoridad sino que a él le pertenece el examen y conocimiento de si las pinturas que representan Heroicas Virtudes, y particulares favores recibidos por

${ }^{29}$ ACM, AC, 1660, 052. 24 de diciembre de 1774, f. 286 v.

30 Sobre el dr. Bisquerra véase Planas Rosselló, A. y Ramis Barceló, R. 2011. La Facultad de leyes y cánones de la Universidad Luliana y Literaria de Mallorca: 156 Madrid: Universidad Carlos III. 
los varones Justos y Santos están comprendidas por el expresado Decreto del Santo Concilio.

[...] Y en fin, cuando el Cabildo estime por conveniente parte en la Curia Eclesiástica, y solicitar la Revocación del Decreto [de prohibición de estampas], no por esto podrá hacer uso de las Estampas prohibidas y tenerlas en su poder, y mucho menos en lugar público; sino que deberá entregarlas con la protesta de que la entrega es por reverencia y en calidad de Depósito interim, que en Juicio Contradictorio quede ejecutoriada la Legitimidad del Decreto, y con salvedad de poderlas recobrar cuando se revoque el citado Decreto de Prohibición. ${ }^{31}$

Por el momento, el deán Juan Despuig consiguió calmar los ánimos y la mayoría de los capitulares acordaron hacer frente a las órdenes diocesanas. Declararon que no iban a cumplir el decreto y, en consecuencia, la iconografía luliana iba a permanecer en su lugar tradicional. Pero Díaz de la Guerra jamás se había caracterizado por ser un hombre que aceptase la subversión. Todo lo contrario, su firme decisión no aceptaba otra cosa.

Mientras el aula capitular se convertía en escenario de enzarzados debates para planificar las estrategias a seguir, el vicario general y mano derecha del obispo, don Gabriel Carrió, había comenzado a mover hilos para hacer cumplir el decreto. Por lo pronto, hizo llamar al sacristán de la Catedral y le ordenó que retirase las estampas de Llull que se dejaban ver en la sacristía capitular. Éste se escudó en que él no tenía autoridad para eliminar la iconografía luliana: “¿Pues quien manda?”, preguntó el vicario, "el sr. Custos", respondió el sacristán. ${ }^{32}$ Y cuando Carrió repitió el mismo proceso con el custos, la respuesta que recibió fue similar. Todo indicaba que la única autoridad capaz de eliminar la iconografía luliana era el Cabildo. Y como ya habían dejado claro, los canónigos no estaban dispuestos a hacerlo.

Finalmente, se desató el desastre. Sin previo aviso, las estampas habían desaparecido de sus lugares tradicionales. El Cabildo, reunido casi de forma permanente, se desvivía "en averiguaciones, para llegar a saber que el Vicario General, de acuerdo con el Prelado y convertido en alguacil ó cosa así, había sido el autor de tan intrépida hazaña". ${ }^{33}$ Las investigaciones no tuvieron éxito $y$, pese a las grandes sospechas que pesaban sobre Carrió y -siempre en la sombra- el mismo obispo, nada

${ }^{31}$ ACM, AC, 1660, 053. 27 de diciembre de 1774, f. 288-290.

${ }^{32}$ Bautista Ensenyat, J. 1920. La baronía de los obispos de Mallorca y Barcelona II: 249 Palma: Escuela- Tipográfica Provincial.

${ }^{33}$ Capllonch Rotger, M. 1900. El seminario de San Pedro. Palma: TipoLipo. 
pudo demostrarse. Además, el robo de las imágenes desató una turbación generalizada, que se extendió más allá del aula capitular. Los miembros del servicio catedralicio comenzaron a experimentar el miedo a sufrir la ira diocesana. Más aún cuando se escuchaban rumores sobre extorsiones y amenazas, como el caso de un reverendo que "había oído decir que se le metería en la cárcel, y aún que ya se le estaba limpiando el cuarto" ${ }^{34}$ donde ocultaba algunas estampas. Díaz de la Guerra, que no se contentaba con la eliminación de los símbolos lulianos que adornaban el edificio, estaba persiguiendo también los rezos privados al Beato mediante estampas, que el personal guardaba en sus habitaciones tradición que también podía verse entre algunos seminaristas del Seminario de San Pedro, y que, de modo similar, intentó extirpar el prelado-. ${ }^{35}$

La persecución iconoclasta en la Catedral sentó un precedente. A partir de ese momento, la incautación de imágenes de Llull asumió una vigorosa fuerza y se extendió a todos los rincones de la diócesis. Y a principios de 1775 , era difícil encontrar elementos iconográficos lulianos expuestos en iglesias y conventos. ${ }^{36}$

\section{LA EXTORSIÓN DE LOS BAUTISMOS Y EL NOMBRE PROHIBIDO}

Si la represión iconográfica abrió la caja de Pandora y desató discordias y violencia en todos los rincones de la isla, hubo otra medida que contribuyó a desestabilizar, todavía más, los pilares del culto luliano, así como a convertir a Díaz de la Guerra en uno de los obispos más impopulares de la historia de la diócesis mallorquina. Se trataba de la prohibición de bautizar con el nombre de Ramón o Ramona, en honor al beato Llull. Medida que se implantó durante el annus horribilis de la campaña antiluliana, concretamente en 1776.

El asunto de los bautismos utilizando el nombre del Beato ya había sido tema de controversia en décadas anteriores, ${ }^{37}$ pero jamás un obispo

${ }^{34}$ ACM, AC, 1660, 053. 27 de diciembre de 1774, f. 294.

${ }^{35}$ Avinyó, J. 1925. Història del Lulisme: 616 Palma: imp. Social.

${ }^{36}$ A lo largo de 1775 , se desató la persecución de imágenes lulianas en las iglesias de Palma, que había comenzado el año anterior. Distintos visitadores episcopales ordenaron la retirada de cuadros en San Antonio de Viana o San Nicolás. Y llegaron a producirse ciertos abusos en algunas iglesias, como el robo de un cuadro en Santa Eulalia o el destrozo de una pintura de Llull. Ferrer i Flórez, M. 2001: 77.

37 El profesor Ramis Barceló constató dos casos claramente controvertidos y relacionados con la cuestión del nombre del Beato impuesto en el bautismo. Lo que evidencia las tensiones que se vivían con respecto al culto a Llull los años anteriores a la llegada de Díaz de la Guerra, y que deben ser tenidas en cuenta. Véase Ramis Barceló, R. 2012: 259-277. 
había llegado tan lejos como para planificar su prohibición expresa. Y, efectivamente, Díaz de la Guerra se había propuesto depurar la vida religiosa mallorquina, cuyo fin incluía en sus planes el destierro total de la devoción a Ramón Llull de la isla. Si, como decía el mitrado, Llull no era beato ni santo, era un ultraje bendecir a los pequeños con su nombre:

Deseando que en los sanctos sacramentos se observe con el mayor cuidado y diligencia las disposiciones de la Santa Iglesia, y que no se introduzcan abusos en lo más Santo de la Religión y en la Sagrada Administración, [...] no imponiendo el de los que no son sanctos Canonizados, ni Beatificados formal ni equivalente, por la Sancta Iglesia, a quien privativamente toca, aunque los padres y padrinos pidan se les imponga por su ignorancia, por el error con que el vulgo da el título de Beato, y aún alguna vez de Sancto. [...] Y haviendo llegado a nuestra noticia que algunos curas y vicarios (sin duda por importunidad de los padres y padrinos) han impuesto o imponen alguna vez el Nombre de Raimundo Lulio, que no es sancto ni beato, ni equivalente, ni aún se halla introducida su causa en la congregación de ritos, ni moralmente lo será en muchos años, lo que no es justo permitir, ni que se crea que semejante abuso sea con aprobación tácita o expresa de S.Sa. Ilustrísima y Reverenda. ${ }^{38}$

A partir de ese momento, cualquiera que se atreviese a bautizar a un neófito con el que pasó a ser conocido como el nombre prohibido, estuvo en el punto de mira del obispo. Las penas para los infractores de la ley episcopal variaban llegando a ser muy extremas; ahora se castigaba "so pena de doscientas libras. [...] De cuatrocientas, encarcelación y privación de officios", llegando a la pena más alta y más temida: "la excomunión mayor ipso facto". ${ }^{39} \mathrm{Y}$ teniendo en cuenta el enrarecido y tenso clima que persistía en la isla desde los inicios de la batida antilulista, no es extraño imaginar el impacto que causó la recepción del nuevo decreto en la población mallorquina; y más concretamente en el Cabildo catedralicio.

Desde los días de la cacería de imágenes lulianas, las relaciones entre el Cabildo y el palacio episcopal eran hostiles, con una violencia sólo disfrazada por las normas de protocolo y jerarquía características de la élite. Pero, aún así, los capitulares se habían unido al Ayuntamiento en sus demandas de frenar la represión. Escribieron alarmados al rey de España, solicitaron la ayuda del Pontífice romano y denunciaron los arbitrios episcopales en la Real Audiencia; pero nada parecía solucionarse en su favor. Todo lo contrario, la prohibición de bautizar con el nombre de pila de Ramón, complicó su situación. Porque el nuevo

${ }^{38}$ AMP, AH 2101/1. 9 de septiembre de 1776, f. 248 v.-249.

${ }^{39}$ ACM, AC 1661, 053. 29 de noviembre de 1776, f. 198. 
mandato episcopal también llegó a las puertas catedralicias, y las medidas que utilizó Díaz de la Guerra para darle cumplimiento fueron, nuevamente, desmedidas.

A finales de agosto de 1776, el vicario general Carrió envió el edicto directamente a los domeros, saltándose la autoridad jerárquica que ejercía el Cabildo, como guardián de la Catedral. Reunidos prácticamente de forma diaria en la sala capitular, los canónigos denunciaban:

que las órdenes dimanadas de V.S. Ilustrísima se pasasen directamente a los oficiales y mercenarios del muy ilustre Cabildo, como lo son los domeros, para la administración de los santos sacramentos, que es propia del Cabildo, a cuyo respeto siempre ha debido preceder el dar la inteligencia con los precisos requisitos al muy ilustre cabildo, como la practicaron los llustrísimos antecesores y V.S. Ilustrísima mismo. ${ }^{40}$

Amparándose en la tradición que había regido la convivencia de ambas instituciones, los capitulares veían en el pasado su salvaguarda para defenderse de los ataques episcopales. Unos ataques que, si hacemos caso de las palabras del Cabildo, rayaban en un abuso de poder flagrante. Por ejemplo, en una carta al rey, denunciaban la intrusión en la Catedral de agentes del palacio episcopal para "substraer [...] el libro de Bautismos, las llaves de los Sanctos Oleos y de la pila bautismal, como así lo mandó [el obispo] a un asistente de domero contra el derecho indubitado del Cabildo". ${ }^{41}$ Tan obcecado estaba el prelado en sus objetivos, que se había propuesto supervisar personalmente el cumplimiento de los edictos episcopales. Para ello, pretendía revisar a fondo los libros bautismales, donde quedaban registrados todos los bautizos realizados en la Seo.

Pero llegando todavía más lejos, actuó personalmente sobre los domeros. Consciente de la resistencia declarada del Cabildo, optó por anular a los brazos ejecutores en los bautismos, valiéndose de todos los recursos a su alcance. Para conseguir que ni un sólo neonato recibiese el nombre prohibido, impuso "multas, prisiones, privación de oficio y otras penas a los domeros, para que no asistiesen a los canónigos en la administración del sacramento del Bautismo". ${ }^{42}$ Éstos, acostumbrados como lo estaban a asistir al acto sacramental en la Catedral, ahora se veían impotentes y temerosos de la ira episcopal. Conocían cuál era su

\footnotetext{
${ }^{40}$ ARM, AA, 0760/011, s/f.

${ }^{41}$ ACM, AC, 1661, 053. 29 de noviembre, f. 198.

${ }^{42}$ ARM, AA, 0760/011, s/f.
} 
deber, pero su miedo a las penas ejercidas por el obispo y su vicario general frustraba todo intento de resistencia al edicto.

La situación en otras iglesias de Palma y la Part Forana no era muy distinta. Eran muchos los sacerdotes indignados ante el edicto, pero la mayoría temían despertar la cólera de Su llustrísima, si no cumplían las nuevas órdenes. Pese a todo, se dieron casos de insubordinación y resistencia, con bautismos organizados con reducido número de asistentes, para evitar que la noticia llegase al palacio episcopal. Además, muchos padres insistían en que sus pequeños recibieran entre sus nombres el de su amado Mártir, que muchas veces era también el de ellos mismos. La situación, en definitiva, era difícil en extremo, siempre ante la vigilancia ejercida por el vicario general Carrió y los constantes informes amontonándose en la mesa del obispo.

El mismo Cabildo, pese a las amenazas y extorsiones que pesaban sobre la sede catedralicia, se negó en rotundo a cumplir las exigencias emanadas del obispo. Sin ánimo de duda, declaró ante los grandes poderes insulares que "nuestro Beato Raymundo goza de inmemorial culto [...], no por la ignorancia y error del vulgo, sino por los mas instruidos e ilustrados con la más sana doctrina obsequiosa y obediente, a los Decretos Pontificios cuales mandan". ${ }^{43}$ El bautismo utilizando su invicto nombre, como defendían los capitulares, era una tradición legitimada por un pasado glorioso y por un culto inmemorial, ratificado por obispos anteriores. Por lo tanto, todos y cada uno de los edictos episcopales que pretendían atentar contra la devoción luliana, se sustentaban en presupuestos erróneos.

En septiembre de 1776, algunos de los miembros del Cabildo más devotos de Llull y que, desde el principio, se habían opuesto a las reformas diocesanas, programaron un ataque directo al edicto episcopal. Haciendo reunir a una gran multitud, los canónigos Antonio Moragues, Nicolás Villalonga y Nicolás Lobo presidieron un bautizo. Cuando el domero Nicolás Massanet procedió a registrar los nombres que recibió el neonato, "uno de ellos [fue] el de Raimundo Lulio, lo que directamente se opone a lo mandado por su Señoría llustrísima". ${ }^{44}$ Pese a que el nombre era accesorio y no el principal, los canónigos eran conscientes de las repercusiones de tal acto, y no dudaron en hacer extender la noticia a todos los rincones de la ciudad de Palma.

Como cabía esperar, Nicolás Massanet fue citado en el Palacio Episcopal. Sometido durante horas a un intenso interrogatorio dirigido por el Vicario General, el domero fue sistemáticamente extorsionado para

43 Ídem.

${ }^{44}$ Biblioteca Bartomeu March -en adelante BBM-, Fondo del Convento de San Francisco, leg. 2, f. 1. 
declarar dónde se hallaba el libro de bautismos en el que había sido registrada el acta bautismal. Del mismo modo, se exigía saber bajo qué permisos había sido programado aquel bautismo que, a los ojos de Díaz de la Guerra, había violado las órdenes episcopales de forma abierta y deliberada. Cuando se le ordenó que entregase el libro, el domero afirmó que "se le quitó de orden del Cabildo, y que no sabe si tiene facultades para recuperarlo". ${ }^{45}$

Pese a los intentos del obispo por frenar la insurrección catedralicia, la mayoría de canónigos se había decantado por la sedición abierta a las órdenes diocesanas. No sólo no cumplieron los edictos episcopales que afectaban al ceremonial e iconografía lulianos, sino que desafiaron abiertamente las prohibiciones en el santo sacramento del bautismo.

\section{CONCLUSIONES}

La represión antiluliana terminó con la partida de Díaz de la Guerra a la península en 1777. Una vez abandonó las costas mallorquinas para responder ante el rey por sus planes de reforma, las instituciones insulares persistieron en restaurar el orden anterior a 1772. El Vicario General Sede Vacante, Nicolás Villalonga -que había sido uno de los tres canónigos que protagonizaron el controvertido bautismo catedralicio de 1776-, procedió a desestabilizar todo el proyecto episcopal. En lo que respecta a la Catedral, las imágenes lulianas que se habían salvado de la persecución, fueron devueltas a sus tradicionales lugares, y el nombre de Ramón volvió a ser parte de los recibidos por los neonatos en el bautismo. Sin embargo, tal maraña de persecución tuvo consecuencias importantes y abrió el camino a una nueva etapa en el lulismo y, por qué no decirlo, en las relaciones en el seno del poder religioso de Mallorca.

En primer lugar, es un hecho constatado que el obispo Díaz de la Guerra jamás dejó indiferente a nadie bajo su pontificado. En lo que respecta a sus ataques al culto luliano, la imagen que dejó en la isla fue claramente negativa. Las medidas que impuso, en este caso sobre el edificio de la Catedral, se caracterizaron por una violencia desmedida y un autoritarismo que no admitía resistencia alguna. Resuelto a hacer cumplir su voluntad, Díaz de la Guerra utilizó todos los medios de que disponía, aún a costa de enzarzarse en serias disputas con los canónigos y abrir un cisma difícilmente resoluble. Si hemos de creer en las palabras del Cabildo, hizo desaparecer imágenes lulianas de la sacristía capitular, ordenó la incautación de los libros bautismales y extorsionó a los domeros y al resto de miembros del servicio capitular:

\footnotetext{
45 Ídem.
} 
unas medidas que reflejaban sus ansias de reformar y uniformizar las dinámicas del culto católico que se venían profesando en Mallorca.

En lo que respecta a los canónigos, quizás por vez primera, temieron verse sometidos a la autoridad episcopal y privados de siglos de preeminente influencia sobre todos los sectores del entramado eclesiástico isleño. No sin razón, habían hecho valer su autoridad durante siglos como elementos clave en la cúspide eclesiástica, llegando a disputar con obispos y virreyes en cuestiones de diversa índole, la mayoría de las veces cumpliendo con sus objetivos. Sin embargo, el pontificado de Díaz de la Guerra significó un punto de inflexión. La campaña antiluliana en la Catedral provocó un impacto considerable sobre los canónigos. Sus desesperados intentos por convencer a Carlos III o al Papa de la necesidad de frenar la política episcopal, son un reflejo claro de las limitaciones que éstos vivían para imponer su autoridad como parte de la cúpula jerárquica. Y cuando el obispo abandonó la isla en marzo de 1777, vigilaron su trayectoria, aún temerosos de nuevos atropellos desde la Corte de Madrid. ${ }^{46}$

Sobre los motivos que llevaron a Díaz de la Guerra a tan violenta disputa, ya se han hecho algunas referencias. El obispo actuó como lo hizo, convencido de que estaba depurando la Diócesis de supersticiones y malos vicios, tan característicos de la herencia barroca. Sabedor de la resistencias que despertó, el prelado era muy consciente de en nombre de quién cumplía los edictos y las razones que lo llevaban a tal fin. A fin de cuentas, únicamente estaba reproduciendo las políticas diseñadas por la Monarquía carolina, actuando como la más alta autoridad en la diócesis de Mallorca. En su mentalidad reformadora, el Cabildo no tenía poder para limitar sus actuaciones. Esto explica su firme actuación en la Seo. Si allí triunfaba, lo haría en todas la iglesias de la isla. O eso era lo que pensaba el obispo cuando inició la represión devocional.

Sobre las consecuencias de su política antilulista, éstas fueron realmente trágicas. La devoción al Beato no desapareció después de aquellos años de controversia, pero jamás volvió a gozar de un beneplácito tan amplio. Tan sólo un año después de la partida del obispo Díaz de la Guerra, y aún en plena reconstrucción del culto público luliano, Carlos III se desligó totalmente de la Causa de la Beatificación de Ramón Llull $^{47}$ mediante una Real Orden de 31 de Agosto de 1778, poniendo fin a

${ }^{46}$ Cuando los canónigos supieron que Díaz de la Guerra se había trasladado a la Corte de Carlos III para dar testimonio al rey de sus años de obispado en Mallorca, decidieron enviar a varios legados, temerosos de la versión que iba a ofrecer el obispo. Referencia: ACM, AA, 1661. 21 de junio de 1777, f. 298.

47 Pérez Martínez, L. 1991. "La Causa Pia Lul-liana. Resum històric". Centre d'Estudis Teològics de Mallorca: 30-31. 
la gran empresa que había unido a los grupos prolulistas en su defensa de Llull durante tantos años. Esta circunstancia demostró que el gran proyecto del obispo no terminó en un total fracaso e hizo conscientes a los poderes insulares, entre ellos al mismo Cabildo, de que el lulismo jamás iba a ser lo que antaño había sido.

\section{BIBLIOGRAFÍA:}

Amengual i Batle, J. 2002. Història de l'Església de Mallorca. Del Barroc a la II.lustració (1563-1800). Palma: Lleonard Muntaner.

Avinyó, J. 1925. Història del Lulisme. Palma: imp. Social. CSIC.

Barrio Gozalo, M. 2010. El clero en la España Moderna. Córdoba:

Bautista Ensenyat, J. 1920. La baronía de los obispos de Mallorca y Barcelona II. Palma: Escuela-Tipográfica Provincial.

Cantarellas Camps, C. 2005. "Iconografía luliana: prototipos y desarrollo histórico." Bolletí de la Societat Arqueològica Lul-liana 61: 213218. Tipo-Lipo.

Capllonch Rotger, M. 1900. El seminario de San Pedro. Palma:

Cassanyes Roig, A. y Ramis Barceló, R. 2012. "El atentado antiluliano de 1699 en el marco ideológico de la Universidad de Mallorca". Memòries de la Reial Acadèmia Mallorquina d'Estudis Genealògics, Heràldics i Històrics 22: 141-166.

Contreras Mas, A. 2008. "Epidemiología rural mallorquina a fines del siglo XVIII". Trabajos de Geografía 37: 83-90.

Cortés Peña, A. 1989. La política religiosa de Carlos III. Granada: Universidad de Granada.

Custurer, J. 1700. Disertaciones históricas del culto al Beato Raymundo Lulio. Palma: Imp. Miguel Capó.

Ferrer i Flórez, M. 2001. "Culte a Ramon Llull: discòrdies i controvèrsies". Studia Lulliana 41: 65-89. 
Ferrer i Flórez, M. 2003. "La convulsió de 1750 referent al culte de Ramon Llull”. Studia Lulliana 43: 103-126.

Furió i Sastre, A. 1852. Episcopologio de la Santa Iglesia de Mallorca. Palma: Imp. Gelabert. Aguilar.

Herr, R. 1971. España y la revolución del siglo XVIII. Madrid:

Juan Vidal, J. 1976. "Crisis agrarias y la sociedad en Mallorca durante la Edad Moderna". Mayurqa 16: 87-113.

Juan Vidal, J. 2010. El sistema de gobierno del reino de Mallorca. Palma: El Tall.

Mateu Mairata, G. 1985. Obispos de Mallorca. Palma: Cort.

Pérez Martínez, L. 1988. "Don Juan Díaz de la Guerra y el lulismo". Anales Seguntinos 5: 95-114.

Pérez Martínez, L. 1989. "Un capítulo sobre el lulismo mallorquín, el Te Deum de 1750". Bolletí de la Societat Arqueològica Lul-liana 45: 333-341.

Pérez Martínez, L. 1991. "La Causa Pia Lul·liana. Resum històric". Centre d'Estudis Teològics de Mallorca: 30-31.

Planas Rosselló, A. 2005. Los Jurados de la Ciudad y Reino de Mallorca (1249-1718). Palma: Lleonard Muntaner.

Planas Rosselló, A. y Ramis Barceló, R. 2011. La Facultad de leyes y cánones de la Universidad Luliana y Literaria de Mallorca. Madrid: Carlos III.

Ramis Barceló, R. 2012. "La imposición del nombre de Ramon Llull en el bautismo: dos casos jurídicamente controvertidos en Mallorca durante el año 1763". Hispania Sacra 64: 259-277.

Rosselló Lliteras, J. 1988. "Don Juan Díaz de la Guerra (s. XVIII)". Estudios Lulianos 28: 51-70.

Sacarès Taberner, M. 2006. "Lulliana imagines: la iconografia luliana de Ramon Llull i els principals episodis de la seva vida". Memòries de la Reial Acadèmia Mallorquina d'Estudis Genealògics, Heràldics $i$ Històrics 16: 139-156. 
LA PERSECUCIÓN DEL LULISMO EN LA CATEDRAL DE MALLORCA 419 DURANTE EL EPISCOPADO DE JUAN DÍAZ DE LA GUERRA (1772-1777)

Sánchez Blanco, F. 2002. El absolutismo y las luces durante el reinado de Carlos III. Madrid: Marcial Pons.

Woloch, I. 1982. Eighteenth-century Europe. Tradition and Progress, 1715-1789: New York. Norton \& Company. 